\title{
BORDERS AND THE CONSTRAINTS ON GLOBALIZATION
}

\author{
Michele Fratianni*
}

\begin{abstract}
$\underline{\text { Abstract }}$
National borders are a big hurdle to the expansion of the open economy. Integration today remains imperfect because national borders translate into trading costs, including differences in monetary regimes. Political borders shelter many goods and services from external competition and, consequently, represent a critical exogenous force in the integration process. Borders are thicker for the small countries than the large countries. Regional trade arrangements have softened or, in some cases, pushed outward national borders, but in the process new borders have emerged. Borders affect also finance and monies. While the speed of financial integration suggests currency consolidation and a decline in the ratio of independent monies to sovereign nations, the formation of multilateral monetary unions pushes the ratio towards unity.
\end{abstract}

Keywords: borders, integration, gravity model, RTA, monetary unions

JEL Classification: E58, F15, F33, G15

Draft date: January, 2004

* W. George Pinnell Professor of Business Economics and Public Policy and Adjunct Professor of Economics at Indiana University, Bloomington, Indiana 47405 (USA). Tel 812-855-9219, Fax 812-855-3354, Email fratiann@,indiana.edu.

\section{INTRODUCTION}


Perfect integration of national markets, just like perfect competition, is an ideal state with strong welfare properties. In practice, however, we live in a world of imperfect integration, with degrees of imperfection that are changing over time. During the gold standard of the late $19^{\text {th }}$ and early $20^{\text {th }}$ centuries, national markets were more integrated than either in the inter-war period or in the immediate post-World War II period. International integration, both real and financial, grew rapidly toward the end of the last century. Newspapers and popular literature have referred to this process as globalization. But globalization, in the strict sense of complete integration of national markets, never existed; nor is it likely to become a reality in the near future. The reason for imperfect integration is that many goods and services are sheltered from external competition either by transport costs, unfamiliarity with foreign trade practices, or outright protection. Political borders translate into thick bands of trading costs and represent a critical exogenous force in the integration process. Firms with market power apply strategies that enhance market segmentation. National policymakers respond to the pressure from domestic producers by relying on borders to give preference to domestic trade over cross-border trade. But domestic biases extend beyond goods and services. Financial and money transactions have also a home distortion.

National borders are changing, albeit slowly, under the pressure of regional and international trade agreements. Regional trade agreements (RTAs) have softened or, in some cases, pushed outward national borders and have created in the process new biases. Not only there is more trade inside RTAs than across RTAs but integration differs across different regions of the world. 
The purpose of the paper is to survey the extent of border-created biases and the implications of borders for tests of integration. By design, I avoid two important topics: the welfare implications of borders and the political-economy of altering or eliminating borders. The rest of the paper consists of three large sections: Section II on the effect of borders on trade in goods and services, Section III on finance, and Section IV on national indepedent monies. Conclusions are drawn in Section V.

\section{BORDERS AND INTERNATIONAL TRADE}

The Heckscher-Ohlin-Vanek (HOV) explanation of international trade is one of the most cherished theorems in economics. According to HOV, comparative advantage is driven by relative factor abundance. The implication is that capital-rich nations export capitalrich products and labor-rich nations labor-rich products. The problem is that this model predicts no better than a coin toss (Bowen et al. 1987). It is hard to explain bilateral trade flows without taking into consideration differences in technology (Harrigan 1997; Eaton and Kortum 2002). Even better predictions are obtained when, in addition to technology differences, consumers are assumed to prefer goods and services produced domestically over those produced across the border (Trefler 1995). The extent of the home bias in consumption is positively related to the size of the economy and negatively related to transport costs and tariff levels (Trefler, Table 6).

Borders create two separate effects. The first, called trading cost, consists of a collection of transaction costs and regime costs, such as transport, administration, differences in legal systems and practices, languages, networks, competitive policies, and monetary regimes. On monetary regimes, more will be said in the latter part of the paper. 
The second consists of tariffs or tariff-equivalent restrictions that aim at discriminating against foreign producers. While for each producer a tariff is a cost like transport, in the aggregate tariffs and tariff-equivalent restrictions redistribute income from foreign producers to domestic producers and consumers. Trading costs, unlike tariffs, absorb resources that melt away like an 'iceberg' as it travels in warm weather.

\section{Gravity model and trade flows}

One way to estimate the border effect is through gravity model of bilateral trade flows. A stylized specification of gravity model goes as follows:

(1) $\ln \left(\mathrm{X}_{\mathrm{ijt}}\right)=\alpha_{0}+\alpha_{1} \ln \left(\mathrm{Y}_{\mathrm{i}} \mathrm{Y}_{\mathrm{j}}\right)_{\mathrm{t}}+\alpha_{2} \ln \left(\mathrm{N}_{\mathrm{i}} \mathrm{N}_{\mathrm{j}}\right)_{\mathrm{t}}+\alpha_{3} \ln \left(\mathrm{DIST}_{\mathrm{ij}}\right)+\alpha_{4} \mathrm{FEAT}_{\mathrm{ij}}+\mathrm{u}_{\mathrm{ijt}}$,

where $X_{\mathrm{ij}}=$ real exports from country $\mathrm{i}$ to country $\mathrm{j}, \mathrm{Y}=$ real gross domestic product (the counterpart of Newton's masses), $\mathrm{N}=$ population (to reflect that larger areas are less open), DIST $=$ distance, FEAT $=$ a vector of dummy variables that capture idiosynchratic country characteristics, and $\mathrm{u}_{\mathrm{ij}}=$ i.i.d. error term. The vector of dummy variables in FEAT can be very large and includes time-invariant factors such as common language, common colonizer, and shared land border and relatively exogenous factors such as common currency and affiliation to a regional trade agreement (RTA). $\alpha_{0}, \alpha_{1}, \alpha_{2}, \alpha_{3}$, and $\alpha_{4}$ are estimatable parameters, with $\alpha_{1}$ having a positive expected sign and $\alpha_{2}$ and $\alpha_{3}$ a negative expected sign. Distance is a proxy of trading costs as defined above.

McCallum (1995) applied this equation to 1988 exports and imports among ten Canadian provinces and thirty states south of the border, coding FEAT equal to 1 for 
inter-provincial trade and 0 for province-to-state trade. The gravity model fits the data quite. The parameter of interest here is $\alpha_{4}$, the size of the border effect. Its point estimate is approximately 3 and statistically significant under a variety of tests, implying that inter-provincial trade is approximately twenty times $(\exp (3) \sim 20)$ larger than trade between provinces and states. The border between Canada and the United States is wide. Helliwell (1996) confirmed these findings with data for the province of Quebec, with the obvious intent of underscoring the implied trade consequences of a possible separation of this province from Canada.

McCallum's findings of very thick borders have been criticized for ignoring the asymmetric impact on trade of barriers between small and large economies and multilateral protection levels. Anderson and van Wincoop (2001, Table 1) re-estimate (1), using McCallum's exact specification and data, alternatively from the viewpoint of Canada and the United States, and find that the border from the Canadian viewpoint is ten times as wide as from the viewpoint of the United States. Since Canada's economy is approximately one-tenth of the United States', the level of protection imbedded in a border is a positive function of the size of the economy. Anderson and van Wincoop's gravity equation predicts that trade flows from region $i$ to region $j$ depend, among other factors, on bilateral and multilateral trading costs. When multilateral costs rise relative to bilateral costs, trade flows rise between $\mathrm{i}$ and $\mathrm{j}$. Furthermore, the smaller the country the larger is the fraction of its output exposed to trading costs An increase in protection redirects output from outside to inside the border, the degree of which being a positive function of the openness of the economy. In sum, protection thickens borders more for the small than the large country. 


\section{$\underline{\text { Convergence tests on prices }}$}

Border effects also show up in prices. The law of one price is the traditional criterion for judging whether two markets are integrated. Transportation costs place a natural wedge on the law of one price. But even adjusting for transportation costs, prices of the same product sold in two different locations may differ because of the power of firms to price discriminate. Less than perfect competition is a necessary but insufficient condition for market segmentation. If consumers can arbitrage price differences, net of transportation costs, market integration can coexist with imperfect competition. In addition to transportation costs and domestic price discrimination, national borders add three types of potential friction: formal trade barriers in the form of tariff and non-tariff protection, informal trade barriers, and exchange rates. Formal trade barriers create a wedge between prices paid by consumers in the importing country and prices charged by the firm in the exporting country. Informal trade barriers are more difficult to quantify because they find their roots in business and social networks. These networks -e.g., groups of the same ethnicity or religion, business alliances, and long-term relationships with foreign suppliers - facilitate international trade through better flows of transnational information and by tempering opportunistic behavior.

The link between the exchange rate and the border occurs through the translation of foreign-currency prices into domestic currency equivalent. Let $\mathrm{P}_{\mathrm{i}}{ }^{\mathrm{x}}$ and $\mathrm{P}_{\mathrm{j}}{ }^{\mathrm{x}}$ be the price of $\operatorname{good} \mathrm{x}$ in countries $\mathrm{i}$ and $\mathrm{j}$, respectively, denominated in the countries' respective currencies; let $\mathrm{S}_{\mathrm{ij}}$ be the exchange rate defined as units of currency i per unit of currency j. The ratio $P_{i}{ }^{x} / S_{i j} P_{j}{ }^{x}$ is the price of good $x$ sold in country $i$ relative to the price sold in 
country $\mathrm{j}$ expressed in the i's currency, and it is equal to 1 if the law of one price holds. The exchange-rate pass-through measures the effects of a depreciation of currency $i$ on local prices. Early work by Kreinin (1977) suggested that the exchange-rate pass-through - that is, the effect of a currency depreciation on local prices - was much less than complete for the United States, Germany, and Japan. Firms can use exchange rate changes to price discriminate, a point made by the pricing-to-market literature; for a review, see Goldberg and Knetter (1997, pp. 1,252-1,262). For example, Marston (1990) finds that Japanese exporters of microwave ovens offset 30 percent of yen appreciation by reducing yen export prices. The implication is that $\mathrm{P}_{\mathrm{i}}{ }^{\mathrm{x}}$ and $\mathrm{P}_{\mathrm{j}}{ }^{\mathrm{x}}$ are sticky in relation to $\mathrm{S}_{\mathrm{ij}}$, and $\mathrm{P}_{\mathrm{i}}^{\mathrm{x}} / \mathrm{S}_{\mathrm{ij}} \mathrm{P}_{\mathrm{j}}^{\mathrm{x}}$ will fluctuate (the higher the correlation between changes in $\mathrm{S}_{\mathrm{ij}}$ and in $\mathrm{P}_{\mathrm{i}}^{\mathrm{X}} / \mathrm{S}_{\mathrm{ij}} \mathrm{P}_{\mathrm{j}}{ }^{\mathrm{X}}$, the higher the degree of price stickiness). Thus, a variable exchange rate adds to the border effect.

Charles Engel and John Rogers (1996) test the hypothesis that price dispersion of similar products is affected not only by distance but by border as well. These authors use Canadian and U.S. city price data for fourteen sub-categories of the consumer price index. Price dispersion is measured by the sample average of the standard deviation of $\Delta \ln \left(\mathrm{P}_{\mathrm{i}}{ }^{\mathrm{X}} / \mathrm{S}_{\mathrm{ij}} \mathrm{P}_{\mathrm{j}}^{\mathrm{X}}\right)$, where $\mathrm{i}$ and $\mathrm{j}$ index cities; the exchange rate is equal to 1 when the pair of cities are located in either Canada or the United States. The descriptive statistics indicate that dispersion differs from product to product, ${ }^{1}$ and is on average higher between acrossthe-border cities than within-the-border cities. Engel and Rogers regress price volatility on distance and a border dummy, and find strong positive and statistically significant

1 The dispersion is much higher in sectors that have significant product differentiation (e.g., ladies' apparel and footwear) than in sectors that sell relatively homogeneous products (e.g., food and alcoholic beverages); see Table 2 in Engel and Rogers (1996). 
effects for both. The headline result is that the Canada-US border is equivalent to a distance of 75,000 miles. Price stickiness accounts for only part of the border effect.

Another way of assessing border effects is to compare domestic deviations from purchasing power parity with international deviations. Let $\mathrm{P}_{\mathrm{i}}$ and $\mathrm{P}_{\mathrm{j}}$ be the price index in location $\mathrm{i}$ and $\mathrm{j}$, respectively. Domestic purchasing power occurs when $\mathrm{P}_{\mathrm{i}} / \mathrm{P}_{\mathrm{j}}=1, \mathrm{i}$ and $\mathrm{j}$ being locations using the same currency; international purchasing power occurs when $\mathrm{P}_{\mathrm{i}} / \mathrm{S}_{\mathrm{ij}} \mathrm{P}_{\mathrm{j}}=1$, i and $\mathrm{j}$ being locations separated by a fluctuating exchange rate. Parsley and Wei (1996) use prices of 51 products for 48 U.S. cities to estimate the convergence rate to (PPP). The authors reject that $\ln \left(\mathrm{P}_{\mathrm{i}} / \mathrm{P}_{\mathrm{j}}\right)$ follows a random walk in favor of the alternative specification of a zero-mean auto-regressive process of order one. The latter yields that implied half-lives deviations from PPP are between four and five quarters for tradables, much lower than half-lives deviations in an international context. This difference in convergence rates is consistent with a border effect. The implication is that if two countries were to adopt the same currency, the border effect would become smaller; more on this below.

\section{$\underline{\text { Regional borders }}$}

RTAs are an important and growing feature of the international trade system; see Fratianni and Pattison (2001) and references therein. RTAs have existed since the middle of the $19^{\text {th }}$ century and were an offspring of colonialism. The newer ones have greater membership diversity, more of an outward orientation, and seek to go beyond 'shallow' goods trade liberalization. The EU is the best example of an RTA that pursues 'deep' integration through liberalization of trade in services and investment and the 
establishment of common technical and regulatory standards, customs formalities, and government procurement practices.

Figure 1 displays raw trade intensity for the main RTAs. Trade intensity is measured by the ratio of intra-regional trade to total trade of the region as a proportion of the region's share of world trade. By construction, the measure is equal to one when intrabloc trade is as intense as trade between the bloc and the rest of the world. A value in excess of 1 indicates that intra-bloc trade intensity exceeds trade intensity with the rest of the world. The data indicate that international trade is regionally concentrated. Regionalization is sharply rising in the ANDEAN Pact and MERCOSUR, slightly rising in the EU and NAFTA, stationary in APEC, and declining in ASEAN. But these ratios ignore the fact that some bilateral flows are larger than others because of income, population, distance and other relevant variables. Thus, the relevant question is whether a regional trade bias exists after accounting for all the factors that appear on the righthand side of (1). To test for a regional trade bias, (1) is modified as follows:

$$
\begin{aligned}
\ln \left(\mathrm{X}_{\mathrm{ijt}}\right)= & \alpha_{0}+\alpha_{1} \ln \left(\mathrm{Y}_{\mathrm{i}} \mathrm{Y}_{\mathrm{j}}\right)_{\mathrm{t}}+\alpha_{2} \ln \left(\mathrm{N}_{\mathrm{i}} \mathrm{N}_{\mathrm{j}}\right)_{\mathrm{t}}+\alpha_{3} \ln \left(\mathrm{DIST}_{\mathrm{ij}}\right)+\alpha_{4} \mathrm{FEAT}_{\mathrm{ij}}+ \\
& +\alpha_{5} \mathrm{RTA}_{\mathrm{ij}}+\alpha_{6} \mathrm{MU}_{\mathrm{ij}}+\mathrm{u}_{\mathrm{ijt}},
\end{aligned}
$$

where a RTA-specific variable has been added to the gravity model to "soak" effects not predicted by the pure gravity model, effects that are presumed to stem from preferential trade policy. Ignore for the moment the MU variable. Frankel (1997, ch. 5) presents 
evidence of regional trade bias - that is, of positive and significant $\alpha_{5}$-for ASEAN, Australia-New-Zealand CER, Andean Pact, and Mercosur. ${ }^{2}$

Figure 1 -Trade Intensity of Selected RTAs

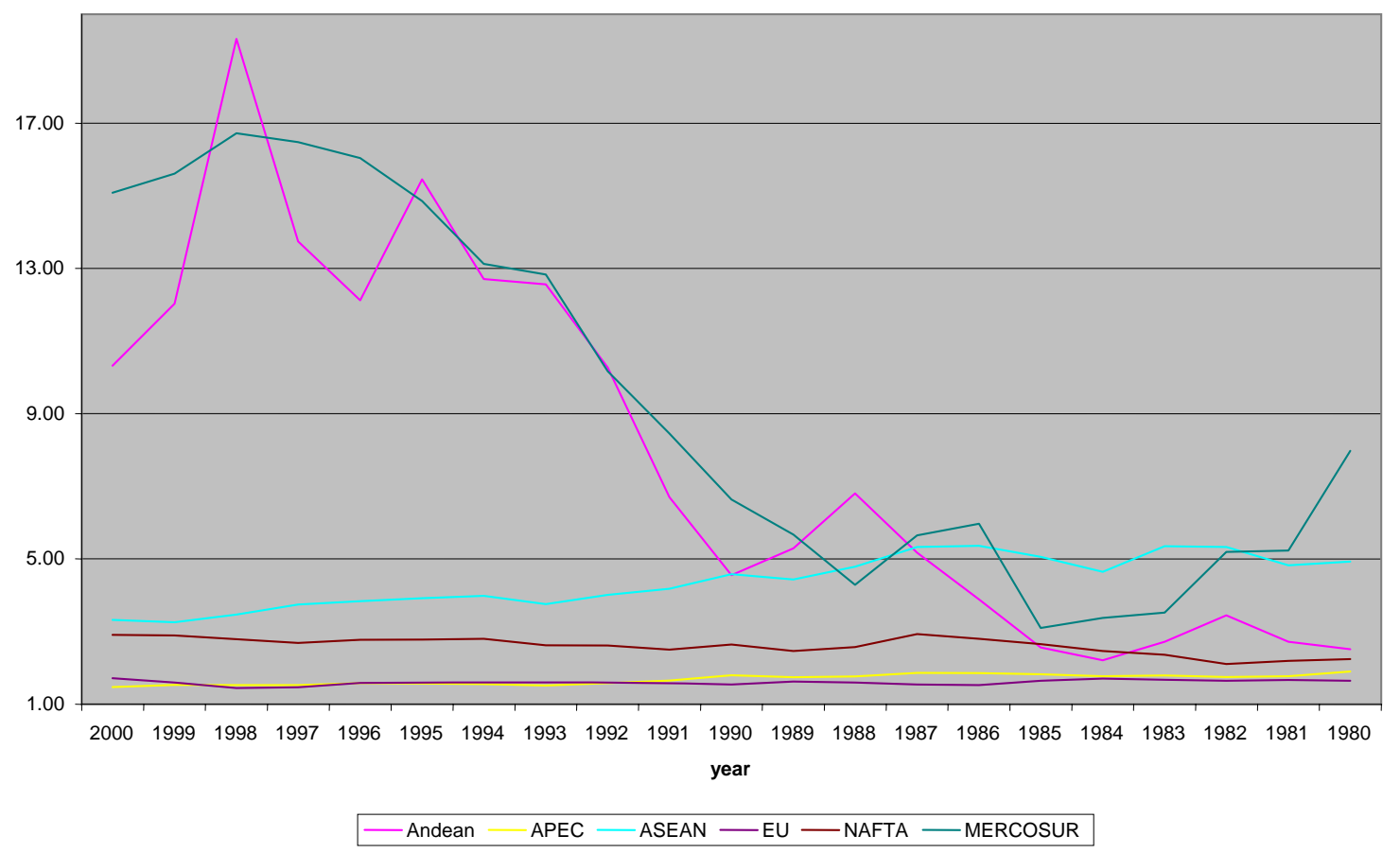

2 ANDEAN consists of Bolivia, Colombia, Ecuador, Peru, and Venezuela; ASEAN of Brunei, Darussalam, Cambodia, Indonesia, Laos, Malaysia, Myanmar, Philippines, Singapore, Thailand, and Vietnam; MERCOSUR of Argentina, Brazil, Paraguay, and Uruguay. 
A more refined test involves defining two dummy variables: an intra-bloc dummy that acquires a value of one when two countries belong to the same RTA, and an extrabloc dummy that acquires a value of one when only one of the two countries belongs to the RTA; for a review of this literature see Soloaga and Winters (2001). The relative size of the dummies can tell us something about trade-creation and trade-diversion effects. For example, should the intra-bloc dummy be positive and the extra-bloc dummy negative, one can compare whether the trade-creation effects, for a given pair of countries, are larger or smaller than the trade-diversion effects. Furthermore and more importantly, the sign of the two dummy coefficients can tell us whether the RTAs are building or stumbling blocs, where "building" means that RTAs enhance expansion of world trade and "stumbling" the opposite. According to the empirical results by Wei and Frankel (1997, Table 1), ASEAN, East Asia (excluding ASEAN) and MERCOSUR have statistically significant positive intra and extra-bloc coefficients. These RTAs appear to have liberalized, not only internally, but also vis-à-vis the rest of the world and consequently have helped multilateralism. For EFTA and NAFTA, on the other hand, the intra-bloc dummy is positive and the extra-bloc dummy is negative, evidence that is consistent with these two RTAs having created a positive internal trade effect but a negative external one. Here, regionalism is not consistent with multilateralism. Finally, for the EU the intra-bloc dummy is negative and the extra-bloc dummy is positive, suggesting that this RTA has generated a negative internal trade effect but a positive external one.

In sum, the evidence points to a regional border effect for many of the most important RTAs. How big is the over-all regional trade bias? It is large according to Rose 
(2000), who estimates the complete (2), that is inclusive of the monetary union dummy variable MU, defined to be one when both countries share the same currency in form or substance. From the pooled sample Rose (Table 2) obtains a point estimate of $\alpha_{5}$ of 0.99 (standard error of 0.08), whereas the point estimate of $\alpha_{6}$ is 1.21 (standard error of 0.14 ). Since $\exp (0.99) \sim 2.7$, countries that belong to the same RTA trade 170 per cent more than countries that do not. Thus, the regional trade bias is somewhat lower than the controversial monetary union effect on trade that will be discussed below.

\section{BORDERS AND FINANCIAL INTEGRATION}

Financial integration is much more than high capital mobility, although there is a tendency in the macroeconomic literature to treat capital mobility and international financial integration as equivalent. High capital mobility is a necessary but not a sufficient condition for financial integration. It takes more than removing restrictions to the flows of capital and foreign exchange transactions to achieve global finance. Unhampered market access, adoption of financial standards, and non-discriminatory financial regulation are part of the requirements for global finance. George von Furstenberg (1998, p. 55) makes this point quite vividly by quoting an assessment of Markus Lusser, the former President of the Swiss National Bank, on Switzerland, "a country that has made the international movement of capital very much its financial business, [but] has a domestic economy that is to a large extent divorced from international price relations and withdrawn from competition by cartels and government regulations." Given space limitation, I will stick to tradition and report on the necessary condition of financial integration. 
The prevailing wisdom is that whatever the degree of "real" integration in the world, financial integration is a notch or two higher. After all, capital, and especially finance capital, moves faster than goods, services, and people. Furthermore, modern-day capital flows, according to Bordo, Eichengreen, and Irwin (1999), after the long pause of the inter-war and Bretton Woods years, have regained and surpassed those of the heyday of the classical gold standard. ${ }^{3}$

\section{$\underline{\text { Tests of integration for financial capital }}$}

Despite the widely held perception of a global financial village, the accumulated evidence suggests financial segmentation, with different degrees depending on assets and countries. Finance too has borders.

Typically, tests of financial integration (or for the necessary conditions of financial integration) rely on the law of one price. Take the covered interest rate parity (CIRP):

$$
i-i^{*}-f p=\left(i-i^{o}\right)+\left(i^{* o}-i^{*}\right)+\left(i^{0}-i^{* 0}-f p\right),
$$

where $\mathrm{i}=$ yield on a domestic assets, $\mathrm{i}^{*}=$ yield on a comparable foreign asset, $\mathrm{fp}=$ forward premium of the foreign currency (spot and forward rates are measured as units of domestic currency per unit of foreign currency), and "o" refers to the offshore location. Several factors can explain departures from CIRP: lack of homogeneity in the underlying

3 Whether capital mobility is higher or lower now than during the gold standard depends to a large extent on whether one measures net or gross capital flows. Net capital flows as a proportion of GDP were higher during the gold standard, whereas gross capital flows are higher today. Bordo, Eichengreen, and Irwin argue that today's capital flows have a much broader reach, in terms of sectors, than in the late $19^{\text {th }}$ century. 
assets, transaction costs, differences in tax rates, differences in credit risk of the issuers, and restrictions on capital flows and foreign exchange market.

Equation (3) separates departures from CIRP in two locational components and everything else. The latter is the CIRP applied to equivalent financial assets traded in the same offshore market. Offshore CIRP has been holding for short-term maturities for widely traded currencies for quite some time (e.g., Fratianni and Wakeman 1982). The locational components reflect controls on capital flows and foreign exchange market as well as sovereign risks. Capital controls started in earnest in the early 1930s and petered out, al least in much of continental Europe, towards the latter part of 1980s. For example, French and Italian tight controls on capital outflows were priced as an exit tax, creating a negative difference between onshore and offshore interest rates in the 1970s and the 1980s (Obstfeld 1995, Table 1; Fratianni and Spinelli 2001, Fig. 10.3). Chile, from 1991 to 1998, enacted a tax on inflows in the form of a zero interest rate reserve requirement. That tax placed a wedge of approximately 3 percentage points between onshore and offshore shortterm interest rates (Herrera and Valdés 2001, Fig. 3).

Only for countries that have no capital and foreign-exchange controls and share similar sovereign risk can onshore CIRP hold. This has been true of the EU countries in the 1990s (Holmes 2001). But for the vast majority of countries that have neither offshore nor forward markets the relevant parity to be tested is the uncovered interest rate parity. ${ }^{4}$ This parity does not hold (see, for example, Montiel 1994) and its failure may well result from the relative weight of country and currency risk premia and their interactions. For most industrial countries, country risk is small relative to currency risk and is relatively stable. For emerging market economies, country risk has a larger weight than in industrial

4 Uncovered interest rate parity can be stated as follows: $i-i^{*}=\left(i-i^{f}\right)+\left(i^{f}-i^{*}\right)$, where the new symbol $\mathrm{i}^{\mathrm{f}}$ is the holding-period yield of a security with similar characteristics of the other two securities, issued by the home government and denominated in foreign currency (say U.S. dollar). The term ( $\left.\mathrm{i}-\mathrm{i}^{\mathrm{f}}\right)$ captures the expected depreciation of the home currency with respect to the foreign currency, whereas the term $\left(i^{\mathrm{f}}-\mathrm{i}^{*}\right)$ captures the difference between the default risk on the home and foreign security as well as the expected value of future changes in the characteristics of the home security, that is country risk 
countries and interacts with currency risk in a complex way. For example, in Argentina country risk was larger than currency risk for most of 2000. In October 2001, the Argentine central bank estimated currency risk at 21.6 percentage points and country risk at 30.3 percentage points (www.bcra.gov.ar, Department of Financial Analysis and Information, October 2001). Possibly, country risk was picking up some of the effects of the impending demise of the Argentine currency board.

In sum, the border effect is imbedded in the two locational terms of (3); these, in turn, can spark departures from onshore CIRP even when offshore CIRP holds. National policymakers can and have used the border to insulate their national money and capital markets from those abroad. It is more difficult to quantify the size of the border effect in the absence of offshore markets.

\section{Tests of integration for physical capital}

Feldstein and Horioka (1980) have challenged the view that markets for physical capital are integrated. Using data from sixteen OECD countries for the period 1960-1974, these authors show that national investment (in fixed capital) as a ratio of GDP (denoted as I) is primarily financed by national saving as a ratio of GDP (denoted as S). In a cross-section regression of the type

$$
I_{i}=\alpha+\beta S_{i}+u_{i} \quad i=\text { country } 1,2, \ldots N
$$

Feldstein and Horioka tested and failed to reject the null of $\beta=1$ of zero (physical) capital mobility. Feldstein and Horioka instigated a vast empirical literature, which found lower values of $\beta$, especially for the 1980 s, but did not disprove its basic tenets (see survey article 
by Coakley et al. 1998). Moreover, there is plenty of criticism in the literature on what this test means for capital mobility. Here are the three most significant ones.

The first criticism regards the identifying assumptions underlying $\beta$. In a classical model the real rate of interest affects I negatively, S positively, and the current-account balance B negatively (and hence the capital-account balance positively), subject to the equilibrium condition of $S_{i}-I_{i}=B_{i}, \beta=I_{r} /\left(I_{r}+S_{r}+B_{r}\right)$, where $I_{r}, S_{r}$, and $B_{r}$ are the slope coefficients of I, S, and B with respect to the real rate of interest (Coakley et al., pp. 172-73). $\beta=1$ when both $S_{r}$ and $B_{r}$ equal zero, and $\beta=0$ (perfect capital mobility) when either $S_{r}$ or $\mathrm{B}_{\mathrm{r}}$ or both tend to infinity. So what drives perfect capital mobility: an infinitely elastic saving rate or an infinitely elastic capital account? The identification problem becomes more complex with general-equilibrium models.

The second criticism concerns $\beta$ and the size of the country. Refer to the equilibrium condition $\mathrm{S}_{\mathrm{i}}-\mathrm{I}_{\mathrm{i}}=\mathrm{B}_{\mathrm{i}}$ in a world of perfect capital mobility. Assume a shock to $\mathrm{S}$. If the shock occurs in a small open economy, the world rate of interest and the national I schedule will remain unchanged, and $\Delta \mathrm{S}$ will be reflected in $\Delta \mathrm{B}$ : for example, a positive shock implies a larger net export of capital, and $\beta=0$. If the shock occurs in a large economy, the world rate of interest and the national I schedule will change. A positive shock implies a lower world rate of interest and a higher national I; hence, $\mathrm{S}$ and I will be positively correlated, and $\beta>0$. Thus, the estimate of $\beta$ is positively correlated with the size of the economies (Harberger 1980). The final criticism concerns the use of cross-section data. Typically, the observations are averages of long annual time series. Given that the long-run value of $B_{i}=0$ (a country can neither permanently lend nor permanently borrow), the value of $\beta$ is biased toward unity. 
Notwithstanding these criticisms, study after study has confirmed the positive association between investment and saving, to the point at which now the finding has been elevated to the rank of a "major puzzle" in international macroeconomics (Obstfeld and Rogoff 2001). It is a puzzle because our strong prior is that capital is mobile, and our prior has been fed by the evidence on covered interest rate parity. But CIRP applies to a narrow spectrum of financial assets and not to physical capital (Dooley et al. 1987, pp. 522-523). For physical capital, the relevant law of one price is real interest rate parity, which can be expressed as follows (Frankel and MacArthur 1988):

$$
r-r^{*}=\left(i-i^{*}-f p\right)+(f p-\Delta e)+\left(\Delta e-\pi+\pi^{*}\right)=0 .
$$

The new symbols are $r=$ the ex-ante real rate of interest, $\Delta \mathrm{e}=$ the expected depreciation of the home currency, and $\pi$ the expected rate of inflation. Equation (5) is consistent with $\beta=$ 0 in (4) (Dooley et al. 1987; Lemmen and Eijffinger 1995). The evidence overwhelmingly rejects (5), and not surprisingly. For (5) to hold, three conditions need to be simultaneously satisfied: covered interest rate parity (the first term in parentheses in the equation); the forward premium as an unbiased estimate of the expected depreciation (second term); and expected purchasing power parity (third term). The first of these three conditions, as we have noted, has empirical corroboration for few currencies and a very narrow set of assets. The second fails miserably (Kang 1992). On the third, we have noted that the half-life of convergence of international real exchange rate is much longer than its domestic counterpart 
(see also Obstfeld and Rogoff 2001). In sum, the failure of real interest rate parity supports the basic contention of Feldstein and Horioka that $\beta$ in (4) is different from zero. ${ }^{5}$

The Feldstein and Horioka finding seems to be consistent with two home biases, one in equities and the other in consumption. The domestic bias in equities is measured relative to the asset diversification predicted by the international capital asset pricing model (Solnik 1996, Ch. 5). Given historical mean returns and variances, the model predicts that the weight of foreign equities should be much higher than the observed weight. The discrepancy between predicted and actual weight remains large even under the assumption of infinite relative risk aversion (Lewis 1999, Table 2). The bias could stem from the failure of the capital asset pricing model to predict diversification, or from the failure of PPP, which is a standard assumption of the international capital asset pricing model, or from the failure of both; there is no way to distinguish between the two. Various attempts to justify the equity home bias have also failed. For some researchers, the bias does not exist because the large standard deviations underlying means and variances of returns makes it difficult to reject the hypothesis that a domestic-only portfolio is worse than an internationally diversified portfolio. ${ }^{6}$

5 There is a long list of financial assets whose prices differ significantly across countries. For example, von Furstenberg (1998) reviews the evidence on the estimated cost of capital in the United States and Japan and insurance premia in countries of the EU. In both cases, differences are too wide to be explained by differences in tax rates.

6The uncertainty problem can be gleaned from the data reported by Lewis (1999: Table 2) on the sample means and standard deviation of the annualized monthly dollar returns of the US stock market and the EAFE index (the "foreign" stock market) for the period 1970-1996. The foreign stock market average return of 12.12 percent exceeded by almost one percentage point the US stock market return of 11.14 percent. However, given that the standard deviations of the foreign and US stock market were 16.85 and 15.07, respectively, one cannot reject the null of mean equality. 
The domestic consumption bias is measured relative to the prediction made by a model where markets are complete in the Arrow-Debreu sense and countries diversify risks due to idiosyncratic shocks (Obstfeld and Rogoff 1996, Ch. 5). In this setting, the growth rate of domestic consumption is equal to that of foreign consumption. The data clearly refute the implication of complete markets (Lewis 1999, Table 1). International risk sharing is not only small relative to prediction but smaller than among regions of the same country. In an early article on the subject, Atkeson and Bayoumi (1993) show that regional capital flows within the United States are larger than among countries. Similar results were obtained for Canada (Bayoumi and Klein 1997). Kleimeier and Sander (2000) provide evidence that financial integration is primarily a regional phenomenon using data from six core European Union countries, Japan and the United States. Not only financial flows but also flows of physical capital are more mobile within the regions of the same country than among countries. Helliwell (1998) reports the results of a Feldstein and Horioka regression with data from the OECD countries and Canadian provinces. The coefficient of the provincial saving variable is negative, statistically significant, and of a size comparable to the coefficient of national saving, implying that capital is very mobile within Canada.

In sum, physical capital is more mobile within the regions of a country than across countries. The same is true for finance capital. Finance capital is more mobile than physical capital. Financial integration in deep RTAs like the EU is higher than global integration. National boundaries are an obstacle to international capital flows and the geographic diversification of assets. As it is true for trade, national borders are a constraint to the expansion of the open economy. Regional arrangements expand national borders and create their own borders. 


\section{BORDERS AND MONIES}

For the late Rudi Dornbusch (2001, p. 238): "A century ago, being a civilized country meant being on the gold standard." Then, after the disruption of financial integration in the wake of World War I, monies became identified with nations, just like flags and airlines. Governments exerted the tightest grip on their monopoly of fiduciary monies: currency substitution did not exist and cross-border money flows were limited except for the key currencies. Money had been nationalized. Yet, throughout the ages, the norm was money competition and cross-border money flows. From the fifth to the seventh century the Byzantine nomisma was the unchallenged coin (Cipolla 1956). The nomisma was displaced in the Low Middle Ages by the Islamic dinar; and the dinar, in turn, was displaced in the higher Middle Ages by the Florentine fiorino, first, and the Venetian ducato, later. These coins were the dollars of the Middle Ages, as Cipolla puts it, because they had high unitary value, stable purchasing power and were issued by political entities with a leading position in international commerce. In more recent time, 1870-1914, the British pound rose to the status of dominant currency, reflecting British attachment to the gold standard and British supremacy in trade and banking.

For the bulk of the $19^{\text {th }}$ century, monies and nations matched with few exceptions. These exceptions tended to be very small open economies with historical ties with the countries' adopted legal tender and often imbedded inside their borders: Andorra, Liechtenstein, Monaco, Nauru, Panama, San Marino, Tuvalu, and the Vatican (see Table 1). The Belgium-Luxembourg Economic Union was the lonely bright spot of a cooperative MU between sovereign states. Towards the end of World War II a handful of small islands in the Pacific adopted the Australian or the US currency as their legal tender. Currency 
consolidation received a modest boost with the formation of the East Caribbean Currency Union in the 1960s, the West African Monetary Union in the 1970s and the Central African Monetary Union in the early 1990s; and a big boost with the European Monetary Union of 1999. All in all, multilateral MUs have been much more significant than unilateral MUs like Ecuador's and El Salvador's.

[Insert Table 1] 
Table 1

Existing Unilateral and Multilateral Monetary Unions with Independent States

\begin{tabular}{|c|c|c|c|c|c|}
\hline $\begin{array}{l}\text { Starting } \\
\text { year }\end{array}$ & Country & \multicolumn{2}{|c|}{ Currency } & $\begin{array}{l}\text { Population } \\
\left({ }^{\circ} 000\right)\end{array}$ & $\begin{array}{l}\text { Income per } \\
\text { capita in US \$ }\end{array}$ \\
\hline \multicolumn{6}{|c|}{ Pre-World War II } \\
\hline 1278 & Andorra & \multicolumn{2}{|c|}{ French franc, peseta \& euro } & 69 & 19,000 \\
\hline 1865 & Monaco & \multicolumn{2}{|c|}{ French franc \& euro } & 32 & 27,000 \\
\hline 1892 & Tuvalu & \multicolumn{2}{|c|}{ Australian dollar } & 11 & 1,100 \\
\hline 1897 & San Marino & \multicolumn{2}{|c|}{ Italian lira \& euro } & 28 & 34,600 \\
\hline 1904 & Panama & \multicolumn{2}{|c|}{ US dollar } & 2,900 & 3,260 \\
\hline 1921 & Liechtenstein & \multicolumn{2}{|c|}{ Swiss franc } & 33 & 25,000 \\
\hline $\begin{array}{l}1922 \\
\text { BLUE }\end{array}$ & $\begin{array}{l}\text { Belgium } \\
\text { Luxembourg }\end{array}$ & \multicolumn{2}{|c|}{$\begin{array}{l}\text { Belgian franc in both countries, } \\
\text { Luxembourg franc in Luxembourg; euro }\end{array}$} & See below & see below \\
\hline 1914 & Nauru & \multicolumn{2}{|c|}{ Australian dollar } & 12 & 5,000 \\
\hline 1926 & Vatican City & \multicolumn{2}{|c|}{ Italian lira \& euro } & 1 & NA \\
\hline \multicolumn{6}{|c|}{ Post-World War II } \\
\hline 1943 & \multicolumn{2}{|l|}{ Kiribati } & Australian dollar & 93 & 830 \\
\hline 1944 & \multicolumn{2}{|l|}{ Marshall Islands } & US dollar & 52 & 2,190 \\
\hline 1944 & \multicolumn{2}{|c|}{ Micronesia } & US dollar & 120 & 2,150 \\
\hline 1944 & \multicolumn{2}{|l|}{ Palau } & US dollar & 19 & 6,730 \\
\hline $\begin{array}{l}1965 \\
\text { East } \\
\text { Caribbean } \\
\text { Currency } \\
\text { Union }\end{array}$ & \multicolumn{2}{|c|}{$\begin{array}{l}\text { Anguilla } \\
\text { Antigua \& Barbuda } \\
\text { Dominica } \\
\text { Grenada (1967) } \\
\text { Montserrat } \\
\text { St. Vincent \& Grenadines } \\
\text { St. Christopher Kitts-Nevis } \\
\text { St. Lucia }\end{array}$} & $\begin{array}{l}\text { East Caribbean dollar; } \\
\text { regional central bank }\end{array}$ & $\begin{array}{l}13 \\
69 \\
72 \\
102 \\
9 \\
116 \\
46 \\
158\end{array}$ & $\begin{array}{l}8,600 \\
9,390 \\
3,180 \\
3,500 \\
3,400 \\
2.820 \\
6,370 \\
3,840\end{array}$ \\
\hline $\begin{array}{l}1973 \\
\text { West } \\
\text { African } \\
\text { Monetary } \\
\text { Union }\end{array}$ & \multicolumn{2}{|c|}{$\begin{array}{l}\text { Benin } \\
\text { Burkina Faso } \\
\text { Ivory Coast } \\
\text { Mali } \\
\text { Niger } \\
\text { Senegal } \\
\text { Togo } \\
\end{array}$} & $\begin{array}{l}\text { CFA franc; regional central } \\
\text { bank; roots go back to } 1959\end{array}$ & $\begin{array}{l}6,300 \\
11,800 \\
16,000 \\
11,300 \\
10,800 \\
9,800 \\
4,700 \\
\end{array}$ & $\begin{array}{l}380 \\
220 \\
660 \\
240 \\
180 \\
490 \\
300\end{array}$ \\
\hline $\begin{array}{l}1994 \\
\text { Central } \\
\text { African } \\
\text { Monetary } \\
\text { Union }\end{array}$ & \multicolumn{2}{|c|}{$\begin{array}{l}\text { Cameroon } \\
\text { Central African Republic } \\
\text { Chad } \\
\text { Republic of Congo } \\
\text { Equatorial Guinea (1985) } \\
\text { Gabon }\end{array}$} & $\begin{array}{l}\text { CFA franc; regional central } \\
\text { bank; roots go back to } 1959\end{array}$ & $\begin{array}{l}15,200 \\
3,600 \\
7,600 \\
2,900 \\
1,200\end{array}$ & $\begin{array}{l}570 \\
290 \\
200 \\
630 \\
3,180\end{array}$ \\
\hline
\end{tabular}




\begin{tabular}{|l|l|l|c|l|}
\hline 1999 & Austria & euro; common central bank & 8,100 & 23,400 \\
& Belgium & & 10,300 & 27,350 \\
& Finland & & 5,200 & 23,500 \\
& France & & 59,400 & 22,000 \\
& Germany & & 82,500 & 22,600 \\
& Greece (2001) & & 10,600 & 11,600 \\
& Ireland & & 3,900 & 23,900 \\
& Italy & & 57,900 & 19,000 \\
& Luxembourg & & 444 & 38,800 \\
& Netherlands & & 16,100 & 23,900 \\
& Portugal & US dollar & 10,000 & 10,800 \\
& Spain & & 41,100 & 14,400 \\
\hline 2000 & Ecuador & US dollar & 12,900 & 1,080 \\
\hline 2001 & El Salvador & 6,400 & 2,040 \\
\hline
\end{tabular}

Sources: Central Intelligence Agency, Factbook; Clément et al. (1996, Box 1); Cohen (1993, Appendix); Edwards (2001, Table 1); Levy-Yeyati and Sturzenegger (2001, Table 1); Statesman's Yearbook, various years; World Bank, World Development Indicators Database; World Currency Yearbook, various years.

Notes: Population and income per capita, in current US dollars, are from the World Bank, World Development Indicator Database; otherwise (indicated with an asterisk) from the CIA, Factbook. Income per capita are GNI for the World Bank and GPD for the CIA.The data are the most recent. The countries listed above are independent states. The number of unilateral currency unions would be longer if we were to consider dependencies, colonies and self-governing regions, such as the Channel Islands (pound), Cocos Islands (Australian dollar), Cook Island (New Zealand dollar), Northern Cyprus (Turkish lira), Greenland (danish krone), Guam (US dollar), Montenegro (euro), Niue (New Zealand dollar), Norfolk Island (Australian dollar), Northern Mariana Islands (US dollar), Pitcairn Island (New Zealand and US dollars), Puerto Rico (US dollar), Saint Helena (pound), American Samoa (US dollar), Tokelau (New Zealand dollar), Turks and Caicos Islands (US dollar), British Virgin Islands (US dollar), US Virgin Islands (US dollar). 


\section{The OCA literature and extensions}

What defines an optimal MU? Are there too many MUs? How many of them should there be? These are the questions raised by the optimal currency area (OCA) literature. If the selection criterion were the efficiency of money as a medium of exchange, the answer would be easy: since the usefulness of money rises the more people use it, the world would the optimal area. But there is more than one criterion. The early OCA literature tried to give an answer to the question of what exchange rate regime is best suited to achieve simultaneously a country's internal balance (non-inflationary trend output) with external balance (sustainable balance-of-payments position). This led Mundell (1961) to emphasize factor mobility as a pre-condition for OCA. Without factor mobility and with price and wage rigidities, it is up to the exchange rate to restore external balance. The national border, as we have seen, creates a discontinuity in price and wage adjustments and factor mobility. Without those borders the size of the optimal currency would change; this is the nexus because national sovereignty and optimal currency area (Cesarano 1997).

Mundell went further and identified common shocks as a second pre-condition of OCA. McKinnon (1963) focused on openness of the economy as a criterion for OCA. The more open the economy, the less important the exchange rate in changing the country's terms of trade; the small open economy is, in fact, defined to be a price taker in the world market. Kenen (1969) underscored product diversification--a more diversified economy is less prone to external shocks and hence does not require changes in the exchange rates. 
Without denying the valuable insights of this literature, its impact has been rather limited because its messages are inconclusive and inconsistent (Tavlas 1994). They are inconclusive in the sense that the criteria cannot be measured unambiguously and consequently weights cannot be assigned to them. They are inconsistent in the sense that one criterion points in one direction (e.g., a small open economy is very open but undiversified), while another points in the opposite direction (e.g., a large economy is relatively closed but has a high degree of product diversification). Furthermore, OCA criteria do not predict what geographical areas in the world should become monetary unions. Political factors that determine national borders also determine monetary unions.

Two big events of the 1990s have reactivated interest in OCAs. The first was EMU, which has shown that the nexus because national sovereignty and monetary union can be broken. The second was the accelerating tempo of currency crises in the world: Mexico in 1994, Southeast Asia in 1997, Russia in 1998, Brazil in 1999, Argentina in 2001, Uruguay, and again Brazil in 2002. While the proximate causes of the crises may be somewhat idiosyncratic, the spread of information and communication technology and rising financial integration are common to all of them. The speed with which we consummate transactions has raised the degree of currency substitution and has rendered currencies of small open economies uncompetitive in relation to those of large and stable economies.

Cohen (2000, p. 29) asserts that "the number of monies that actually succeed in gaining some degree of general acceptance is sure to be reduced dramatically." Dornbusch (2001) titles his article: "Fewer Monies, Better Monies;" Rogoff titles his: “Why Not a Global Currency?" Alesina and Barro (2002) formulate a model that predicts 
that the equilibrium ratio of independent currencies to countries falls as the number of countries in the world rises. Countries become smaller as their number increases. Since the relative importance of cross-border transactions is inversely related to country size, the value of a monetary union also rises because of its ability to lower trading costs. The denationalization of money, on the other hand, creates benefits and costs. The benefits accrue in the form of policy credibility for those countries that cannot pre-commit to stable inflation rates through domestic discretionary policies. The costs manifest themselves in the inability to use national monetary policy to offset idiosyncratic shocks. Common sense suggests that very small countries gain more in credibility than they lose by giving up discretionary monetary policy. The opposite is true for very large countries. The battle is fought in the middle.

Returning to the theme of currency consolidation, the world has lost 14 national currencies and gained one since 1999 (Table 1). It would appear that the ratio of independent currencies to sovereign states has indeed dropped. But this measurement assumes that EMU, in steady state, is a collection of 12 sovereign states. If instead EMU is counted, expectationally, as one country the ratio has changed only marginally. In fact, the distinction between unilateral and multilateral MU alters the interpretation of the Alesina-Barro model. If currency consolidation occurs through dollarization, the ratio of currencies to countries declines as the world becomes more atomistic. If instead currency consolidation occurs through multilateral MUs that also require political unifications, the ratio does not change. Two points are worth emphasizing.

The first is that unilateral MUs, as opposed to multilateral MUs, face a severe disadvantage that is not sufficiently emphasized by the literature: the link between money 
and power. Take Argentina, for example, a country for which many experts had advocated dollarization as an improvement over the currency board (see, for example, Schuler and Stein (2000)). The government of Argentina made overtures to the US government about the terms of a possible dollarization, namely whether the United States would be willing to share seigniorage, give access to the Federal discount window, and cooperate on bank supervision. The response to that inquiry can be found in the 'International Monetary Stability Act of 1999' (the Act). ${ }^{7}$ This Act states unequivocally that "the Federal Reserve System has no obligation to act as a lender of last resort to the financial systems of dollarized countries; ...no obligation to consider the economic conditions of dollarized countries when formulating or implementing monetary policy; and the supervision of financial institutions in dollarized countries remains the responsibility of those countries." (Section 2, part (b)). The Act allows for the U.S. Treasury to rebate 85 per cent of the seigniorage resulting from currency flows after "official" dollarization; there is no rebate on the stock of currency before official dollarization. To enjoy the rebate on the new currency flows, dollarized countries would have to surrender U.S. Treasury securities and receive in exchange an equal amount of U.S. currency and interest-bearing U.S. perpetuities. The Act states that coupon payment on these perpetuities "is rendered null and void upon a United States declaration of war on the country or a publicly issued statement by the Secretary [of the Treasury] that the country is no longer officially dollarized..." (Section 6).

The declaration-of-war clause underscores the nexus between money and power. Countries that are considering the adoption of the dollar as their legal tender cannot

7 The Act was introduced by Senator Connie Mack in the U.S. Senate (S. 1879) on November 8, 1999 and 
ignore the possibility that their monetary systems may be disrupted by the United States in times of conflict. It happened to Noriega's Panama in March of 1988, when the U.S. government put a payment squeeze on the country. Banks were closed for two months and Panamanian real GDP suffered a sharp drop (Moreno-Villalaz 1999). These factors may explain why fully dollarized economies tend to be small. What country of the size of Argentina or Brazil would acquiesce politically to a clause that its monetary system would be under potential threat of a foreign government?

The second point is that multilateral MUs are much more complex than unilateral MUs and require, to function properly, a high degree of inter-state cooperation (Cohen 1993) and fiscal redistribution (Kenen 1969). It is exactly these aspects that give rise to the prediction that multilateral MUs cannot be stable without ultimately becoming fiscal or political unions. Thus, in an expectational sense, the East Caribbean Currency Area, the West African Monetary Union, the Central African Monetary Union and EMU imply a long-run reduction in the number of countries, leaving the equilibrium ratio of independent currencies to countries unchanged.

\section{The trade-money causality}

Frankel and Rose (1998) and Rose (2000) have questioned the direction of causality from "real" integration to monetary integration and have proposed instead the hypothesis that OCA criteria are endogenous. The direction of causality can go the other way, with monetary unification enhancing economic integration, not only through a higher degree of price transparency and lower transaction costs but also through more predictable costs 
and product differentiation. Monetary unification is an engine of structural change and as such generates endogenous OCA criteria.

To test this proposition, Rose estimates (2) above and finds that the estimate of $\alpha_{6}$, the MU coefficient, ranges from 0.87 in 1970 to 1.51 in 1990 and 1.21 for the pooled regression (Rose 2000, Table 2). Using the latter and noting that $\exp (1.21)=3.35$, the implication is that monetary unification can more than treble trade, an effect that dwarfs the impact of exchange rate variability on trade and is 25 percent larger than the noted regional effect.

Quite a controversy has risen around Rose's large empirical effect of MU on trade. For Persson (2001), the countries in Rose's MU group are much too different in terms of income, dimension and geographical proximity from the countries in the control group. Just like in medical experiments, the treated group must be made homogenous with respect to the control group. After rebalancing the two groups, Persson re-estimates the gravity model and obtains much lower estimates of $\alpha_{6}$ and much higher standard errors. A similar, but narrower, objection has been raised by Mélitz (2002) who finds that the selection bias of the MU group stems from the fact that these countries share close trade relations and political affinity. Using the same data, Mélitz disentangles regional trade agreement and political union effects from MU effects and arrives at a preferred estimate of $\alpha_{6}$ that implies that MU doubles trade. For Pakko and Wall (2001), the problem with Rose's results stems from the estimation technique. Countries differ in so many ways that it is impossible to capture all differences by expanding the list of FEAT (see eq. (1)). Pakko and Wall advocate the specification of fixed effects to correct the 
bias that may arise from omitted variables. They re-estimate the model using the same Rose (2000) data set and find that both $\alpha_{5}$ and $\alpha_{6}$ are statistically not different from zero. Also Glick and Rose (2002) re-estimate (2) with fixed effects but on a larger data set (1948 to 1997) than Rose (2000) and more observations of switches in and out of MUs, and find an estimate of $\alpha_{6}$ that is half of the estimated $\alpha_{6}$ obtained from pooled data.

In sum, the endogenous OCA literature focuses on the role of MU as a catalyst of 'real' integration, in contrast to the passive role of money assigned by the traditional OCA literature. This idea finds more favor than the quantitative impact of monetary unification on trade flows. The state of the art is that the estimate of $\alpha_{6}$ is sensitive to sample and empirical methodology. As to borders, we recall that sustainable multilateral MUs require a permanent modification of the national border in the sense of a fiscal and or political unification. The border is the real exogenous force in the expansion of multilateral MUs.

\section{SUMMARY AND CONCLUSIONS}

This paper has dealt with the constraints that national and regional borders place on the international integration of goods, services, capital, and monies. Despite the clamor of anti-globalists, the world is far from an integrated village. It took us almost a hundred years to regain the degree of integration that existed during the gold standard. Integration today remains imperfect because national borders translate into trading costs, including differences in monetary regimes. Political borders shelter many goods and services from external competition and, consequently, represent a critical exogenous force in the integration process. 
Borders are thicker for the small countries than the large countries and adjust to the inter-play of bilateral and multilateral trading costs. Not surprisingly, it is small countries that tend to be the most favorable to a liberal trade system. The trend of regionalism has softened or, in some cases, pushed outward national borders, and in the process has created new biases. Not only is there more trade inside RTAs than across RTAs, but integration differs across different regions of the world.

The significance of the border goes beyond goods and services. It affects physical and finance capital as well. Physical capital is more mobile within the regions of a country than across countries, and the same is true for finance capital. Finance capital is more mobile than physical capital. Financial integration in RTAs like the EU is higher than global integration. As it is true for trade, national borders are a constraint to the expansion of the financial economy; regional arrangements have expanded national borders and created borders of their own.

After World War I virtually each country had its own fiduciary money and restrained currency substitution. Monies went in unison with flags and airlines. The speed of financial integration seems to call for massive currency consolidation. Yet, the record shows that except for small cases of unilateral MUs, the significant reductions in the number of currencies have occurred through the formation of multilateral MUs, such as the East Caribbean Currency Union, the West African Monetary Union, the Central African Monetary Union and the European Monetary Union . But since multilateral MUs cannot be stable without ultimately becoming fiscal or political unions, it is not clear whether financial integration will ultimately reduce the ratio of independent monies to sovereign nations. 


\section{REFERENCES}

Alesina, Alberto and Barro, Robert J. (2002). Currency Unions. Quarterly Journal of Economics 117(2): 409-436.

Anderson, James E. and van Wincoop, Eric (2001). Gravity with Gravitas: A Solution to the Border Puzzle. NBER Working Paper 8079, January.

Atkeson Andrew and Bayoumi, Tamin (1993). Do Private Capital Markets Inspire Regional Risk? Evidence from the United States and Europe. Open Economies Review 4(3): 303-324.

Bayoumi, Tamin A. and Klein, Michael W. (1997). A Provincial View of Economic Integration. IMF Staff Papers 44 (December): 534-556.

Bordo, Michael D., Eichengreen, Barry and Irwin, Douglas A. (1999). Is Globalization Today Really Different Than Globalization A Hundred Years Ago?. National Bureau of Economic Research, Working Paper 7195.

Bowen, Henry P., Leamer, Edward E. e Leo Sveikauskas (1987) "Multicountry, Multifactor Tests of the Factor Abundance Theory." American Economic Review 77, 5: 791809.

Ceasarano, Filippo. (1997). Currency Areas and Equilibrium. Open Economies Review 8:51-59.

Cipolla, Carlo M., (1956), Money, Prices, and Civilization in the Mediterranean World. Princeton, N.J.: Princeton University Press.

Coakley, Jerry, Kulasi, Flarida and Smith, Ron (1998). The Feldstein-Horioka Puzzle and Capital Mobility: A Review. International Journal of Finance and Economics 3: $169-188$.

Clément, Jean A.P. with Mueller, Johannes, Cossé, Stéphane and Le Dem, Jean (1996). Aftermath of the CFA Franc Devaluation. Occasional Paper 138. Washington, D.C.: International Monetary Fund.

Cohen, Benjamin (2000). Life at the Top: International Currencies in the Twenty-First Century. Princeton Essays in International Economics n. 221. Princeton, N.J.: Princeton University Press.

(1993). Beyond EMU: The Problem of Sustainability. Economics \& Politics 5:187-203.

Dooley, Michael, Frankel, Jeffrey A. and Mathieson, Donald J. (1987). International Capital Mobility: What Do Saving-Investment Correlations Tell Us? IMF Staff Papers 34: 503-29.

Dornbusch, Rudiger (2001). Fewer Monies, Better Monies. American Economic Review Papers and Proceedings, 91, 2: 238-42.

Eaton, Jonathan and Kortum, Samuel (2002). Technology, Geography and Trade. Econometrica 70 (5): 1,741-1,779.

Edwards, Sebastian (2001). Dollarization and Economic Performance: an Empirical Investigation, NBER working paper n. 8274.

Engel, Charles and Rogers, John H. (1996) How Wide is the Border? American Economic Review 86 (5): 1,112-1,125. 
Feldstein, Martin and Horioka, Charles Y. (1980). Domestic Saving and International Flows. Economic Journal 90, (June): 314-329.

Frankel, Jeffrey A. (1997). Regional Trading Blocs in the World Economic System. Washington, D.C.: Institute for International Economics.

and MacArthur, Alan T. (1988). Political vs. Currency Premia in the International Real Interest Differentials: A Study of Forward Rates for 24 Countries. European Economic Review 32(5): 1,083-1,121.

Frankel, Jeffrey A. and Rose, Andrew K. (1998). The Endogeneity of the Optimum Currency Area. Economic Journal 108: 1,009-1,025.

Fratianni, Michele and Wakeman, Lee M. (1982). The Law of One Price in the Eurocurrency Market. Journal of International Money and Finance 1: 307-323.

Fratianni, Michele and Pattison, John (2001). International Organizations in a World of Regional Trade Agreements: Lessons from Club Theory. The World Economy 24(3): 333-358.

Fratianni, Michele and Spinelli, Franco (2001). Storia Monetaria d'Italia: Lira e Politica Monetaria dall'Unità all' Unione Europea. Milano: Etas.

Glick, Reuven and Rose, Andrew K. (2002). Does a Currency Union Affect Trade? The Time-Series Evidence. European Economic Review 46: 1125-1151.

Goldberg, Pinelopi K. and Knetter, Michael K. (1997). Goods Prices and Exchange Rates: What Have We Learned? Journal of Economic Literature 35(3): 1,2431,272 .

Harberger, Arnold (1980). Vignettes on the World Capital Market. American Economic Review 70: 331-37.

Harrigan, James (1997). Technology, Factor Supplies, and International Specialization: Estimating the Neoclassical Model. American Economic Review 87(4): 475-494.

Helliwell John F. (1996). Do National Borders Matter for Quebec's Trade? Canadian Journal of Economics 29(3): 507-522.

— (1998). How Much Do National Borders Matter? Washington, D.C.: Brookings Institution Press.

Herrera, Luis O., and Valdés, Rodrigo O. (2001). The Effect of Capital Controls on Interest Rate Differentials. Journal of International Economics 53: 385-98.

Holmes, Mark J. (2001). Some New Evidence on Exchange Rates, Capital Controls and European Union Financial Integration. International Review of Economics and Finance 10:135-146.

Kang, Heejoon (1992). Forward Exchange Rates as Unbiased Predictors of Future Spot Rates: A Review and Re-interpretation. Open Economies Review 3: 215-232.

Kenen, Peter B. (1969), 'The Theory of Optimal Currency Areas: an Eclectic View', in Robert A. Mundell and Alexander. K. Swoboda (eds.), Monetary Problems of the International Economy, Chicago: Chicago University Press.

Kleimeier, Stephanie, and Sander, Harald (2000). Regionalisation versus Globalisation in European Financial Market Integration: Evidence from Co-integration Analyses. Journal of Banking \& Finance 24:1005-1043.

Kreinin, Mordechai E. (1977). The Effect of Exchange Rate Changes on the Prices and Volume of Foreign Trade. IMF Staff Papers 24(2): 297-329. 
Lemmen, Jan J.G. and Eijffinger, SylvesterC.W. (1995). The Quantity Approach to Financial Integration: The Feldstein-Horioka Criterion Revisited. Open Economies Review 6(2): 145-165.

Levy-Yeyati, Eduardo and Sturzenegger, Federico (2001). Dollarization: A Primer. Manuscript.

Lewis, Karen K. (1999). Trying to Explain Home Bias in Equities and Consumption. Journal of Economic Literature 37 (June): 571-608.

Marston, Richard (1990). Pricing to Market in Japanese Manufacturing. Journal of International Economics 29 (3-4): 217-236.

McCallum, John (1995). National Borders Matter: Canada-U.S. Regional Trade Patterns. American Economic Review 85(3): 615-623.

Mélitz, Jacques (2002). Geography, Trade and Currency Union. Paper presented at the Conference on "Euro and Dollarization: Forms of Monetary Union in Integrated Regions," Fordham University and CEPR, New York, April 5-6, 2002.

McKinnon, Ronald I. (1963). Optimum Currency Areas. American Economic Review 52, September: 615-623.

Montiel, Peter J. (1994). Capital Mobility in Developing Countries: Some Measurement Issues and Empirical Estimates. The World Bank Economic Review 8:3:311-350.

Moreno-Villalaz, J. L. (1999). Lessons from the Monetary Experience of Panama: a Dollar Economy with Financial Integration. The Cato Journal 18, 3: 421-439.

Obstfeld, Maurice. (1995). International capital mobility in the 1990s. In Peter B. Kenen (Ed.), Understanding Interdependence: The Macroeconomics of the Open Economy. 201-261. Princeton: Princeton University Press. and Rogoff, Kenneth (1996). Foundations of International Macroeconomics. Cambridge, MA: MIT Press.

(2001). The Six Major Puzzles in International Macroeconomics: Is There a Common Cause? In Ben Bernanke and Kenneth Rogoff (Eds.), NBER Macroeconomics Annual 2000: 339-390. Cambridge, MA: MIT Press.

Pakko, Michael R. and Wall, Howard (2001). Reconsidering the Trade-Creating Effects of a Currency Union. Federal Reserve Bank of St. Louis Review 83, 5: 37-45.

Parsley, David C. and Wei, Shang-Jin (1996). Convergence to the Law of One Price without Trade Barriers or Currency Fluctuations. Quarterly Journal of Economics 111(4): 1,211-1,236.

Persson, Torsten (2001). Currency Unions and Trade: How Large Is the Treatment Effect? Economic Policy October: 435-448.

Rogoff, Kenneth (2001). Why Not a Global Currency? American Economic Review Papers and Proceedings, 91,2: 243-47.

Rose, Andrew K. (2000). One Money, One Market: The Effects of Common Currency on Trade. Economic Policy 30, (April) 9-45.

Schuler, Kurt and Stein, Robert (2000). The Mack Dollarization Plan: an Analysis. Paper presented at the Conference "Dollarization: A Common Currency for the Americas," Federal Reserve Bank of Dallas, March 6, 2000.

Solnik, Bruno (1996). International Investments. 3rd ed. Reading, MA:, Addison-Wesley. Soloaga, Isidro and Winters, Alan L. (2001), Regionalism in the Nineties: What Effect on Trade?, North American Journal of Economics and Finance 12, 1:1-29. 
Tavlas, George (1994). The Theory of Monetary Integration. Open Economies Review 5(2): 211-230.

Trefler, Daniel (1995). The Case of the Missing Trade and Other Mysteries. American Economic Review 85: 1,029-1,046.

von Furstenberg, George M. (1998). From Worldwide Capital Mobility to International Financial Integration. Open Economies Review 9(1): 53-84.

Wei, Shang-Jin and Frankel, Jeffrey A. (1997). Open versus closed trade blocs. In T. Ito, and Anne O. Krueger (Eds.), Regionalism versus Multilateral Trade Arrangements. 119-139. Chicago: The University of Chicago Press. 